Jurnal Ekonomi Pembangunan, 18 (2), 2017, 159-174

\title{
The Influence of Exchange Rate on Indonesian CPO Export
}

\begin{tabular}{|c|}
\hline Agung Prasetyo ${ }^{1 *}$, Sri Marwanti ${ }^{2}$, Darsono $^{2}$ \\
${ }^{1}$ Agribusiness Master Program, Universitas Sebelas Maret \\
${ }^{2}$ Agribusiness Study Program, Faculty of Agricultural, Universitas sebelas Maret, \\
Jln. Ir. Sutami No. 36 A, Surakarta 57126 \\
${ }^{*}$ Corresponding Author: agungpras17@gmail.com \\
\hline
\end{tabular}

Recieved: June 2017 | Revised: November 2017 | Accepted: November 2017

\begin{abstract}
This study analyzes the effect of the exchange rate (IDR to US Dollar) on Indonesian CPO exports using Error Correction Model (ECM). The result of ECM analysis showed that exchange rate has a weak effect on Indonesian CPO export. These were due to several things; first, it takes a time to produce CPO. Second, importers are unaware of price changes. Third, policy factors, such as refusal of Indonesian CPO in USA and imposition of high import duty tariff in France. Fourth, price factor of CPO substitution goods and negative issues in the palm oil industry. Fifth, Indonesian exporters were less creative in marketing CPO products than Malaysia. ECM analysis also resulted that CPO production and CPO prices have no effect on Indonesian CPO exports, while the price of soybean oil and CPO production in the previous month has a strong influence on Indonesian CPO exports. Indonesian CPO export is inelastic.
\end{abstract}

Keywords: CPO, Export, ECM

JEL Classification: F19, Q17

How to cite: Prasetyo, A., Marwanti, S., \& ., D. (2017). The Influence of Exchange Rate on CPO Exports of Indonesia. Jurnal Ekonomi Pembangunan: Kajian Masalah Ekonomi Dan Pembangunan, 18(2), 18-33. doi:https://doi.org/10.23917/jep.v18i2.4233

DOI: https://doi.org/10.23917/jep.v18i2.4233

\section{Introduction}

Indonesia's CPO production (Crude Palm Oil) increases rapidly from 1980-2015 due to an increase in production and widespread Oil palm plantations (Oosterveer, 2015). According to the Directorate General of Plantation (2016), in 1980 Indonesia's CPO production was only 721.17 thousand tons and in 2015 to 31,284 million tons or an average growth of $11.65 \%$ every year. The high level of CPO production growth in Indonesia was not followed by the growth of downstream processing industries $\mathrm{CPO}$ (Department of Industry, 2012), although world demand for vegetable oil especially $\mathrm{CPO}$ and its derivatives increased from year to year as well (USDA, 2017). High levels of CPO production, high CPO processing, and world demand are the factors driving Indonesia to boost CPO exports to countries around the world (Peñarandaa et al. 2015).

The export of a country is an excess of domestic supply or production of goods or services not consumed by the consumers of the country concerned or not stored in stock (Seyoum, 2009). Indonesia's export performance continued to improve from period to period. In terms of value, the contribution of the agricultural sector is still below from other sectors, but in terms of the 
growth rate of agricultural exports has exceeded from other sectors (Ervani, 2013). Indonesia's export CPO from 1981 to 2015 tended to increase from an average growth of $23.82 \%$ per year. In 1981, Indonesia's CPO export volume was only 196,361 ringtones with the export value of US $\$ 106,936$ million, and in 2015 export volume rose to 19,043 million tons worth US $\$ 11,581$ billion (Directorate General of Plantation, 2016). According to Salvatore (2009), the lower the price of a commodity will be the less number of commodities offered by the manufacturer, and vice versa. The amount of supply of a commodity is generally influenced by the price of the goods concerned, the price of the substitute goods, the production capabilities, the policy, the exchange rate, and other external factors. The exchange rate of a currency will increase the export of a good in a floating exchange rate system and the concept of excellence, the magnitude of the exchange rate is very influential on the competitive advantage of a commodity so that the developed commodity has a broader competitiveness than the same type of commodity from other countries (Hatab and Eirik, 2014). Exchange rate commonly used in international trade activities in Indonesia is the IDR to US dollar.

Figure 1 shows that the growth rate of Indonesia, Malaysia and Colombia CPO exports and the growth rate of the IDR against the US dollar in 2011-2015. The average growth of Indonesian CPO exports to 2011-2015 is 3.83\% per year and is well below Malaysia and Colombia with average growth of $15.02 \%$ and $49.78 \%$. The IDR exchange rate against the US dollar during the period of $2011-2015$ averaged $8.39 \%$ per year on average. This shows the facts and anomalies of interesting conditions to be observed. The weakening IDR exchange rate against the US dollar should spur Indonesia's CPO export activities higher because producers and exporters will get higher profit stimulus when exporting to the condition, but the fact that shows the weakening of the IDR against the US dollar is followed With CPO exports declining by $16.81 \%$ in 2015 from CPO exports to 2014.

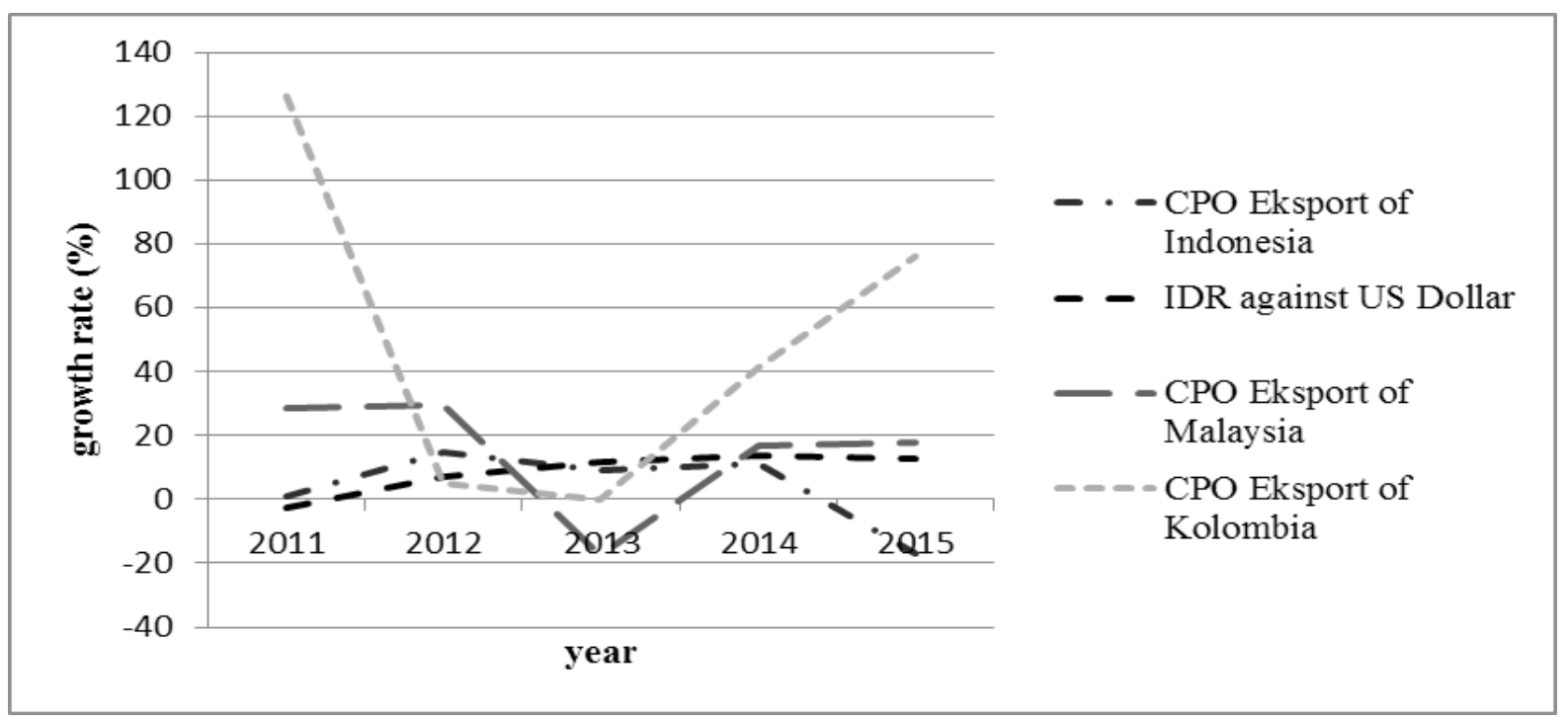

Source: Bank Indonesia and UN Comtrade, 2011-2015.

Figure 1. The growth rate of Indonesian CPO exports, Malaysia, Colombia and the IDR exchange rate against the US dollar 


\section{Jurnal Ekonomi Pembangunan, 18 (2), 2017, 159-174}

Sovacool, 2014) faces stiff competition and pressure with other $\mathrm{CPO}$ exporting countries in the world. The weakening of the IDR should be followed by an increase in CPO exports and further enhance and strengthen the position of CPO competitiveness in the world.

Marshall-Lerner condition is a condition in which devaluation policy can successfully improve the balance of trade if the elasticity of export and import goods is more than one or is elastic. If the elasticity of the imported or exported goods against the elastic price is elastic, then the devaluation or depreciation will be able to encourage exports to reduce imports. On the contrary, if the elasticity of export and import goods is not elastic, then devaluation or depreciation policy will be difficult to improve the trade balance (Sumantyo and Anggraeni (2016). Marshall-Lerner condition also states that volume change will dominate change of value, So although the import value will increase and the export value will decrease, but the increase in export volume and the decrease of import volume will predominate so that the total trade balance will improve. Nevertheless, there is a tendency that elasticity will be lower in the short term until the condition of Marshall-Lerner is likely to be met only in the medium- and long-term (Baek, 2007). The explanation of phenomena is based on the fact that international trade usually runs for a pre-determined contract so that the export volume changes and Imports can not change immediately following the change of exchange rate.

This paper aims to analyze the effect of the IDR exchange rate of US Dollar against the export of Indonesian CPO and know the elasticity of Indonesian CPO exports to the time of change in IDR exchange rate. This paper attempt to provide a better illustration of the effect of exchange rate on CPO exports Indonesia, therefore it can provide input to policy makers, producers and exporters of CPO in response to exchange rate conditions to take decisions on Indonesia's CPO export policy decisions and further increase export and strengthen the competitiveness of Indonesian CPO in the world.

\section{Methods}

Research on the effect of exchange rate values on the export of Indonesian CPO is done from December 2016 until April 2017. The research focuses on Indonesia's CPO export during the period of January 2010 until December 2015. The data used in this research is secondary data. Secondary data used is time series data with a period of January 2010 - December 2015. Secondary data taken in this research is the export volume of $\mathrm{CPO}, \mathrm{CPO}$ export price, soybean oil price as $\mathrm{CPO}$ substitution goods, exchange rate (IDR against the US dollar), CPO production, the Indonesian consumer price index and the consumer price index of the Americas. The CPO export analyzed in this study is more devoted to export volume based on HS (Harmonized System) 1996 code 151110. Secondary data is obtained from government agencies or institutions (BPS RI), Ministry of Trade of the Republic of Indonesia (Ministry of Trade), Ministry of Agriculture of the Republic of Indonesia (Kementan RI), World Bank (WB), UN comrade (The United Nations Commodity Trade Statistics Database), Bank Indonesia (BI), research journals, and related literature.

The effect of IDR exchange rate can be analyzed by ECM (Error Correction Model). ECM is a technique for correcting short-term imbalances to the long-term balance introduced by Sargan and popularized by Engle and Granger (Maryatmo (2010), Wibowo (2015)). ECM aims to address issues of unstandardized and unreliable series of notes. The results of short-term forecasts with long-term growth are unequal to one period to be corrected in the next period, so no information is omitted for long-term forecasts (Lee, 2013). ECM is expected to explain the effect of IDR exchange rate (changed in a relatively short period) to Indonesian CPO export (monthly).

There are several conditions for the ECM model to be used to analyze a problem (wibowo, 2015). First, at least one variable used is not stationary. Second, the equation used has cointegration relations. Third, the form of the equation is univariate. Unit root test is a test that 


\section{Jurnal Ekonomi Pembangunan, 18 (2), 2017, 159-174}

can be viewed as a stationary test of data. The test is used to observe certain coefficients of an autoregressive model estimated to have one or no value. This study uses two unit tests developed by Dickey-Fuller (DF) to find out the root unit in the variable at the first difference. The assessment for the Dickey-Fuller test is defined by equation (1) to (3).

$\Delta \mathrm{Yt}=\delta \mathrm{Yt}-1+\mu \mathrm{t}$

$\Delta \mathrm{Yt}=\beta 1+\delta \mathrm{Yt}-1+\mu \mathrm{t}$

$\Delta \mathrm{Yt}=\beta 1+\beta 2 \mathrm{t}+\delta \mathrm{Yt}-1+\mu \mathrm{t}$

$\beta 1, \beta 2$, and $\delta$ are estimation parameters and $\mu t$ is white noise error. The hypothesis of testing is done by the hypothesis $\delta=0$. The difference between these three equations is only in the deterministic components of $B 1$ and $32 \mathrm{t}$. The first equation (1) is a random walk. The second equation (2) is estimated using to intercept, and the third equation (3) includes to intercept and trends. The Augmented Dickey-Fuller (ADF) tests are used to know the root unit in the variables at the level of the second, third and so on. This test is done if the data is not stationed on the first difference (Nanang, 2010). The unit roots estimation of autoregressive doing with the assumption of $t$-statistics ADF equal to the value of t-statistics DF (Subiyakto and Algifari, 2016), formulated in equation (4).

$\Delta \mathrm{Xt}=\mathrm{a} 0+\mathrm{a} 1 \mathrm{~T}+\mathrm{a} 2 \mathrm{BX} \mathrm{t}+\sum_{i=1}^{k} d i B i \Delta \mathrm{Xt}+$ et...

where, $\Delta \mathrm{Xt}$ is $\mathrm{Xt}-\mathrm{Xt}-1$, BXt is $\mathrm{Xt}-1$, $\mathrm{Xt}$ is the variable observed in period $t, T$ is the time trend, B is the slowness-time operation or time lag and $\mathrm{K}$ is the time lag $(\mathrm{k}=\mathrm{N} 1 / 3, \mathrm{~N}$ is the number of samples). The test criterion is done by comparing the statistic value of $\mathrm{DF}$ or ADF variable with a critical value in McKinnon table. There are unit roots and non-stationary data if the statistical value of $\mathrm{DF}$ or $\mathrm{ADF}$ variable is greater than the critical value in the Mckinnon table and if the statistical value of DF or ADF variable is smaller than the critical value In table
Mckinnon make data there is no root of the unit and stationary data. Degree of integration test is done if data still not stationary. The integrity projection is intended to know the degree or the order for the differentiation of how the observed data will be stationary. The integration degree test is generally an extension of the unit root test and is not necessary if after the DF or ADF tests results show stationary data.

The data co-integration can be known in various ways, such as Engle-Granger (EG) test, Engel-Granger augmented test (AEG) and Durbin-Watson Co-integrating Regression (CRDW) test. In this research, the residual value is used to calculate Engle-Granger value. Equation from used for Engle and Granger tests are in the equation (5) and (6).

$\Delta \mu \mathrm{t}=\lambda \mu \mathrm{t}-1$

$\Delta \mu \mathrm{t}=\lambda \mu \mathrm{t}-1+\alpha i \sum_{i=1}^{m} \Delta \mu \mathrm{t}-\mathbf{1}$

If the value of $\mu$ denotes the value 0 , then the variables in the model are not co-integrated. The residual value obtained is then tested for its static, if stationary at the level order the data is to be co-integrated (Wibowo, 2015).

The basic equations and co-integration test for this study are described in equation (7):

$Y t=f(H t$, Hst, Ert, Prt, Prt-1)...

Or it can be written in the following form:

$\mathrm{Yt}=$ BHt a1 Hsta2Erta3Prta4Prt-1a5eu

Alternatively, can be written in the following natural logarithm:

$\operatorname{LnYt}=\mathrm{a} 0+\mathrm{a} 1 \mathrm{LnHt}+\mathrm{a} 2 \mathrm{LnHst}+\mathrm{a} 3 \operatorname{LnErt}+\mathrm{a} 4 \mathrm{~L}-$ $n$ Prt + a 5 LnPrt $-1+U$

$\mathrm{a} 0=\ln \beta$

Notes:

Yt : Month export volume of CPO (ton) 


\section{Jurnal Ekonomi Pembangunan, 18 (2), 2017, 159-174}

Ht : CPO export price in month $t$ normalized by Indonesian CPI (IDR/kg)

Hst : The price of soybean oil in month $t$ normalized by the US CPI (IDR/kg)

Ert : The IDR exchange rate against US Dollar in month t (IDR/US Dollar)

Prt : CPO production in month $\mathrm{t}$ (ton)

Prt-1 : Total CPO production in month t-1 or previous month (ton)

a0 : constants

a1,2,3,4,5,, : regression coefficients

$\mathrm{U} \quad$ : error

Co-integration can be used as an Error Correction Term (ECT) when the qualification of stationary testing. Stationary can be seen in the lower-t-statistic value of the Mackinnon Criteria. The Error Correction Term (ECT) used is the earlier period of PE. It is intended to equate variables with other dependent variables that use the natural logarithm (ln) in the previous period. The coefficient should be a negatively significant value in order that a predefined equation can be used complete with the ECM model (zhang et al. 2015). The general model of ECM is as follows:

$\Delta y t=\beta 0+\beta 1 \Delta x t+\gamma(x t-1-y t-1)+\mu t$.

Notes :

$\Delta y t \quad$ : First Difference of Y(yt-yt-1)

$\Delta \mathrm{xt} \quad$ : First Difference of $\mathrm{X}(\mathrm{xt}-\mathrm{xt} 1)$

yt : endogenous variable

xt : exogenous variable

ut $\quad$ : Error term

To know the model specification with ECM is a valid model, it can be seen on the statistical test result of residual from first regression. If the test results from the ECT coefficient are significant, then the model specification observed is valid. The ECM model in this study is in equation (11).

$\Delta \mathrm{LnYt}=\mathrm{a} 0+\mathrm{a} 1 \Delta \mathrm{LnHt}+\mathrm{a} 2 \Delta \mathrm{LnHst}+\mathrm{a} 3 \Delta \mathrm{LnErt}$ $+\mathrm{a} 4 \Delta \operatorname{LnPrt}+\mathrm{a} 5 \Delta \operatorname{LnPrt}-1+\mathrm{a} 6 \mathrm{ECT}-1+\mathrm{U}$.
Furthermore, the regression model is tested using statistical test (coefficient of determination, F-test, and t-test) and classical assumption test (normality, multicollinearity, autocorrelation and heteroscedasticity).

Elasticity is the ratio of the proportional change of a variable with the change of other variables (Salvatore, 2009). The elasticity of exports is the degree of sensitivity of changes in quantity of good exported to changes in the price of exported goods. The coefficient of elasticity is the number which shows the ratio to the change in quantity of good and the price changes. The size of the coefficient of elasticity of CPO exports can be calculated following the elasticity formula for supply as follows:

$\mathrm{Es}=\frac{\Delta Q}{\Delta P} X \frac{P}{Q}$

Notes :

Es : Export elasticity

Q : Amounts exported (tonnes)

$\mathrm{P} \quad$ : Price of goods (IDR / $\mathrm{mt}$ )

$\Delta \mathrm{Q}$ : Changes in quantity of supply (tones)

$\Delta \mathrm{P} \quad$ : Price change of goods (IDR/mt)

The value of export elasticity more than one indicates that $\mathrm{CPO}$ exports are elastic. Other results indicate inelastic if the value is less than one. The unitary elasticity is obtained when the export of elasticity is one.

\section{Results and Discussion}

\subsection{Unit Root and Data Co-integration}

There are several conditions for the ECM model to be used to analyze a problem. A model must satisfy the data stationary criteria and data co-integration before using ECM analysis. Including a nonstationary variables in the equation results in a standard error being biased and resulting in incorrect conclusions. Table 1 describes the stationary test of the data on to this study.

Based on table 1, it was found that all variables of stationary research at first difference in $95 \%$ 


\section{Jurnal Ekonomi Pembangunan, 18 (2), 2017, 159-174}

confidence level. Determination of significance level by comparing $t$ values of the statistic of each variable and critical value of MacKinnon. If the statistical $t$ value of the variable is smaller than the critical value of MacKinnon, then there are no unit roots and stationary data. After a unit root test, a data cointegration test can be performed. Cointegration tests are done by using Engle and Granger method. From the regression estimation result, the residual will be tested stator in the same way for unit root test. The data must be cointegrated in a level order in order that the ECM method is appropriate and feasible for use of the equation. Based on secondary data analysis, statistic $t$ values and probability of residual unit root test at level order with DF test approach is $-6,01$ and 0,00 at $95 \%$ confidence level. It means that data had cointegrated and ECM is feasible to be used in equation to know the factors that affect the export volume of Indonesian CPO.

Table 1. Unit Root Test on First Difference

\begin{tabular}{ccc}
\hline Variable & t statistic & Probability \\
\hline D(LNERt) & $-6.16^{*}$ & 0.0000 \\
D(LNHSt) & $-5.10^{*}$ & 0.0001 \\
D(LNHt) & $-10.25^{*}$ & 0.0001 \\
D(LNPRt) & $-3.12^{*}$ & 0.0303 \\
D(LNPRt- $)$ & $-3.71^{*}$ & 0.0062 \\
D(LNY) & $-8.72^{*}$ & 0.0000 \\
\hline
\end{tabular}

Source: Analysis of secondary data, 2017. Description: * Real at $95 \%$ confidence level, $\mathrm{D}=\Delta$, MacKinnon critical values for $1 \%, 5 \%$ and $10 \%$ are $-3.527045,-2.903566$ and -2.589227

\subsection{Estimation Result}

ECM model can be formed if there is cointegration between free variables and a dependent variable indicating a long-term balance of the relationship between independent variables and a dependent variable that may in the short term occur imbalance. The ECM model can be used when the ECt-1 variable is significantly negative. Table 2 shows the coefficients of the ECt1 variable of -0.7746 and has a probability of 0.00 (less than a 0.05). It shows that the ECM feasible to be used to analyze Indonesian CPO exports and the previous period imbalance is corrected in the current period of 77.46 percent. The result of estimation of variables affecting Indonesian CPO export shows Adjusted R2 value of $45.88 \%$. It indicated that CPO price variables, IDR exchange rate, soybean oil price, $\mathrm{CPO}$ production and $\mathrm{CPO}$ production in the previous month are able to explain Indonesian CPO exports by $45.88 \%$ and the rest $54.12 \%$ explained other variables that are not included in the model. The positive sign on the coefficient of free variables of soybean oil price and CPO production in the previous month showed that if the price of soybean oil and CPO production in the previous month rose by a few percent, it will affect the percentage increase of the export volume of Indonesian CPO.

\subsection{F Test}

$\mathrm{F}$ test used to know the influence of dependent variable simultaneously on to independent variable. Based on Table 2, the dependent variable of CPO price, IDR exchange rate, soybean oil price, $\mathrm{CPO}$ production and $\mathrm{CPO}$ Production of the previous month together have real effect Of Indonesian CPO exports (probability (F-statistics) is 0.00 smaller than a (0.05)).

\section{4 t Test}

T test used to know the effect of a dependent variable on to independent variable partially. Based on Table 2, it was found that the variables of soybean oil price and CPO production in the previous month had a strong effect on Indonesian CPO exports. Although the effect is weak (real at $80 \%$ confidence level), The exchange rate influences the export of CPO. CPO prices and CPO production in month $t$ have no effect on Indonesian $\mathrm{CPO}$ exports. 
Jurnal Ekonomi Pembangunan, 18 (2), 2017, 159-174

Table 2. Estimated Results of Independent Variables on Indonesian CPO Exports

\begin{tabular}{lllccc}
\hline No & \multicolumn{1}{c}{ Variable } & Coefficient & Standard Error & t-statistic & Prob. \\
\hline 1 & C & -0.0046 & 0.05 & -0.09 & 0.92 \\
2 & D(LNERt) & $-3.7608^{* *}$ & 2.68 & -1.40 & 0.16 \\
3 & D(LNHSt) & $4.5760^{*}$ & 1.46 & 3.14 & 0.00 \\
4 & D(LNHt) & $-0.6025^{\mathrm{ns}}$ & 0.65 & -0.93 & 0.35 \\
5 & $\mathrm{D}(\mathrm{LNPRt})$ & $0.2195^{\mathrm{ns}}$ & 0.35 & 0.62 & 0.53 \\
6 & $\mathrm{D}(\mathrm{LNPRt}-1)$ & $0.7515^{*}$ & 0.34 & 2.24 & 0.02 \\
7 & $\mathrm{E}_{\text {Ct.1 }}$ & $-0.7746^{*}$ & 0.10 & -7.59 & 0.00 \\
\hline Coefficient of Determination $\left(\mathrm{R}^{2}\right)$ & 0.5052 & & & \\
Adjusted $R^{2}$ & 0.4588 & & & \\
F-statistics & 10.8895 (prob. 0.00$)$ & & & \\
Durbin Watson test & 2.1979 & & & \\
Number of Observation & 72 & & & \\
\hline
\end{tabular}

Source: Analysis of secondary data, 2017.

Noted: * real at $95 \%$ confidence level, ** real at $80 \%$ confidence level, nsnot significant $\mathrm{D}=\Delta$

The results of research that states the exchange rate of rupiah has a weak and negative impact on Indonesian CPO exports in accordance with a research done by Abidin (2008), Rosita et al. (2014), Sonaglio et al. (2016), Khalighi and Fadaei (2017) who found that exchange rates have a weak influence on a commodity (CPO). The results of this study also contradict the findings of Ahmed (2009), Efendi and Sawitriyadi (2009), and Chaudhary et al. (2016) assumed that the rupiah exchange rate did not affect the export of Indonesian CPO. Sulistyanto and Akyuwen (2011) and Widyastutik and Asiqin (2011) proven that the rupiah exchange rate against the US dollar had a strong and positive influence on Indonesian CPO exports.

\subsection{The Influence of Soybean Oil Prices on Indonesian CPO Exports}

The price of soybean oil has a strong influence to Indonesian CPO exports due to the position of soybean oil as a substitute for CPO. Based on USDA data (2017), world soybean oils consumption of 2015-2016 amounted to 53.649 million matrix tons. Consumption of high soybean oil will be reduced if the price of soybean oil rose, then soybean oil consumers in the world will switch to using CPO and can trigger an increase in CPO import demand. An increase in demand will be responded by Indonesia. Indonesia will increase CPO exports to importer countries in the world.

\subsection{The Influence of Exchange Rate on Indonesian CPO Export}

Table 2 shows that the exchange rate influences the export of $\mathrm{CPO}$, although the effect is weak (real at $80 \%$ confidence level). This indicates that the IDR exchange rate can not directly affect CPO exports although, in exchange rate system theory, exchange rate devaluation can increase the volume of export goods directly (Kumar, 2014). The influence of the weak exchange rate is caused by several things such as production, it takes a time to produce $\mathrm{CPO}$, thus increasing the export of CPO also takes time, and consequently, the change in IDR exchange rate does not respond with increasing CPO exports. In addition to the time slowness factor in producing CPO, changes in the IDR exchange rate did not respond well because importers were unaware of price changes and the lag between decision making and timing of $\mathrm{CPO}$ orders from importer countries.

The policy factor in the importer country also affects the amount of Indonesian CPO exports. For example, the United States rejects 


\section{Jurnal Ekonomi Pembangunan, 18 (2), 2017, 159-174}

CPO from Indonesia in 2012 on the grounds that Indonesia's CPO is not included as a sustainable product. Indonesia's CPO is unlikely to be used for biofuel feed stocks as well as other derivative products of the United States. In contrast to the United States, the French Government imposed a policy of imposing high tariffs on import duties for products of major deforestation impacts on the world. The policy is a move by the French government to show the government's attitude that strongly supports environmental protection efforts. The Government of France considers Indonesia's CPO included in that category. Internationally, CPO importer countries want the inclusion of RSPO (Roundtable Sustainable Palm Oil) certification on Indonesian CPO. The RSPO aims to reduce the reduction of forest covered, reduce greenhouse gas emissions from land use change and compliance with legal requirements. The influence of the policy taken by importer countries is to make CPO prices uncompetitive in the world market. The uncompetitive price makes the exchange rate prevailing over upon the country does not become a trigger for producers and exporters to increase the quantity of CPO exports.

The other factors are more caused by factors outside the CPO industry such as price growth of CPO substitution goods (soybean oil prices) and environmental negative issues in the palm oil industry, especially deforestation and forest fires. This external factor can make consumers reluctant to consume CPO from Indonesia. The policy factors of importing countries and other factors outside the CPO industry are actually well responded through the promotion of Indonesian CPO to Asian countries such as India, China, and Pakistan, but Indonesian exporters are less creative than Malaysia in responding to $\mathrm{CPO}$ demand in that country. Indonesia does not take steps like Malaysia by establishing CPO shelter and selling CPO derivative products such as cooking oil, margarine, and oleo chemicals in export destinations. Malaysia receives many benefits by building CPO shelters in the ports of importing countries (Choong and McKay, 2014). Malaysia can respond to a new demand for CPO more quickly because the request can be directly met from the shelter. This is much more beneficial to importer countries than having to wait for shipment of CPO from Indonesia to meet demand. Another advantage that Malaysia gets is that they can sell CPO derivative products in importer countries so that they get greater valueadded than selling CPO in raw form and this also frees Malaysia from import quota of CPO. CPO is limited by quota is CPO product in the raw form and not CPO derivative products.

\subsection{The Influence of CPO Prices on Indonesian CPO Export}

CPO prices are generally lower than other vegetable oils (soybean oil, sunflower oil, and canola seed oil). CPO prices are lower due to lower CPO production costs and the high productivity of palm oil per unit area (Syaukat (2010), GAPKI (2017)). The production cost of palm oil is only USD 180/tons, while soybean oil is USD 315/ tons and rapeseed oil is USD 750/tons. In view of this condition, many European and American countries have adopted policies to protect their farmers. The refusal of Indonesian CPO in the United States in 2012, the application of high CPO imports duties in France and various certification requirements for $\mathrm{CPO}$ exports are an example of that policies. In addition, European and American countries also campaigned on the negative issue of palm oil in the hope that consumers will again consume soybean oil. Negative issues developed in the palm oil industry are primarily related to carbon emissions, ecosystem damage from peat lands, environmental degradation, deforestation and land fires. This negative issue is indicated as a "trade war " because there has been a shift in the use of vegetable oil sources from corn oil, soybean oil, sunflower seed oil, and canola oil to palm oil. Increased production and consumption of palm oil worldwide has reduced the demand for vegetable oils produced largely by western countries. Preventive policies on local farmers in 


\section{Jurnal Ekonomi Pembangunan, 18 (2), 2017, 159-174}

European and American countries have resulted in Indonesia's CPO price not being competitive in the world market. The uncompetitive prices make it difficult for Indonesia to increase CPO exports to the European and American countries.

The prices of CPO in recent years are less profitable for producers and exporters. Low CPO prices add to the reluctance to boost CPO exports even though the government has imposed a zero percent export duty (if the CPO price is below 750 U.S. dollars per metric ton). The decline in CPO prices is primarily due to lower demand for CPO in Europe and the Middle East. The decline in demand is inseparable from the fall in world crude oil prices (USD 30 per barrel), which then affects the price of other commodities. China's slowing economic growth and stagnation in Europe also caused a drop in global CPO prices (GAPKI, 2017). The success factors of soybean and rapeseed crops oil production in western countries also caused a decrease in world CPO prices. The success of the harvest increases the world's vegetable oil stock so as to lower the price of vegetable oil as a whole. The ineffectiveness of biodiesel mandatory program in Indonesia and Malaysia has also become one of the factors of declining world CPO prices. Biodiesel is a promising product and can add more value of CPO products. The biodiesel programs in Indonesia and Malaysia is expected to increase CPO market demand globally so that it will boost CPO price in the international market, but the program can not be implemented well in both countries, so the program is not yet beneficial to improve world CPO price.

Prices have no effect on boosting CPO export volume due to the growth of $\mathrm{CPO}$ production tends to take time (gestation period) and the existence of agreements with importers stating the purchase of $\mathrm{CPO}$ at a certain price. The waiting time to produce CPOs has resulted in Indonesia not being able to respond to price changes. Price changes can only be the limited response to domestic CPO stocks. The export-import works agreement on CPO trading generally to describe and states price agreements to exporters and importers. The price of this deal is fixed and involves a certain volume of CPO demands. The price of this agreement binds producers and exporters to not be able to change prices following the changes in CPO prices that exist in the world market. $\mathrm{CPO}$ prices agreements on producers and exporters with importer will benefit producers and exporters if the price is higher than the price of CPO applicable to the world market and will harm if the price is below the price of CPO in the world market. The effect of this agreement places the producer and exporter as the recipient of the price and not the price determinant. As a recipient of prices, producers and exporters can not respond to changes in world prices by increasing CPO exports to importing countries.

\subsection{The Influence of CPO Production on Indonesian CPO Export}

Based on table 2, CPO production in month $\mathrm{t}$ has no effect on Indonesian CPO exports. It can be explained that in the processing of $\mathrm{CPO}$ from palm trees there is uncertainty due to climate influence, pest and disease and technical management of the plantation itself. This uncertainty causes the amount of production to be uncertain. Uncertain production levels result from CPO exports also becoming uncertain amount, availability, and length of time to fulfill export demand. During 2010-2015, there are climate and weather uncertainties in Indonesia. Indonesia had a long drought due to El Nino storm. The long drought has caused drought in most of Indonesia's oil palm plantations and decreased the potential for palm oil production in Indonesia. This decline in production potential affects the decline in Indonesian CPO exports.

In addition to the uncertainty factor, producers need time to produce and process fresh fruit bunches (FFB) of palm oil into CPO. The CPO processing chain starts from harvesting and transporting fresh fruit bunches to the location of palm oil processing plants. After arriving at the oil palm plant, fresh fruit bunches are weighed and processed into CPO. The resulting CPO is 


\section{Jurnal Ekonomi Pembangunan, 18 (2), 2017, 159-174}

then stored and delivered to the port to be used for the fulfillment of domestic demand as well as export demand. This palm oils/oiled production chain eventually resulted in the resulting CPO not being directly exported to the destination countries. Finally, Indonesian CPO exports unresponsive if there is a change in CPO demand and changes in CPO prices in the world market.

Another factor that resulted in CPO production in month $t$ has no effect on Indonesian CPO exports is the existence of contractual ties and agreements between producers and exporters with importer countries. The agreement explains that there is no increase in new CPO demand from importer countries if the previous request has not been fulfilled. The effect of this agreement resulted in CPO production being retained in the domestic export market, thus increasing storage costs and slowing down the timing of export activities to the next export activity. The agreement also resulted in CPO exports activities to be dependent on the distance and duration of CPO shipments of the importing country. The longer of CPO arrive in the importer country, the new demand will be longer and the response from new CPO exports to demand will be recorded in the next month's export period.

The impact of uncertainty production and agreement with importer countries are in accordance with the results of the analysis explaining and proving that the variables of CPO production in the previous month strongly influenced the export of Indonesian CPO. CPO production in the previous month also acted as stock of Indonesian CPO which will be used to fulfill domestic and export demand when there are new demand happen.

\subsection{Indonesian CPO Export Elasticity}

The concept of absolute purchasing power parity (PPP) states that in an open economy the general price level of similar goods will be the same in each country when converted from local currency of each country. The devaluation or depreciation of the local currency against foreign currencies resulted in the price of imported goods being more expensive and the prices of exported goods becoming cheaper and thus impacting on the increase of exports. Conversely, if the policy of evaluation or appreciation is done the price of imported goods becomes cheaper and the price of exported goods is more expensive so that it will increase the import. This is possible because consumers are always thinking to improve the quality of life and reduce expenditure needs by buying goods cheaper in the market (Kumar, 2014). The absolute purchasing power parity concept explains the direct relationship between the exchange rate and the price of a good or commodity, especially consumer goods, raw materials and capital goods. Indirect indices of the exchange rate and prices are transmitted through domestic demand and net external demand or exports and imports. This indirect relationship usually occurs because changes in IDR exchange rate devalued will increase the income of exporters in the country so that it will increase their demands for good and services in the country. The impact on this increase in demand will raise domestic prices (Arifin, 2008). The Marshall-Lerner theory states that volume changes will dominate the change of value, so that even if the value of imports will increase and the value of exports will decrease but the increase in export volume and the decrease in import volume will dominate so that the total trade balance will improve.

The effect of price changes on a number of goods offered by producers or requested by consumers can be seen through the effect of elasticity. The elasticity approach focuses on the relationship between exchange rate and current account balance. Trade balances performance may improve over the long term when there is depreciation or devaluation if the amount of elasticity of demand for export and import prices against real exchange rate is more than one or absolute. The elasticity of Indonesia's CPO exports is the level of sensitivity of changes in the amount of Indonesian CPO exported to the change of CPO 


\section{Jurnal Ekonomi Pembangunan, 18 (2), 2017, 159-174}

export prices in Indonesia. It may also be used indirectly to assess the sensitivity of Indonesian CPO exports to changes in the IDR exchange rate. The coefficient of elasticity of Indonesian CPO exports is presented in the table 3 .

Table 3. Elasticity of Indonesian CPO Exports, 2010-2015

\begin{tabular}{lc}
\hline Year & Coefficient of Elasticity \\
\hline 2010 & 0.5955 \\
2011 & 0.0883 \\
2012 & 0.1056 \\
2013 & 0.5539 \\
2014 & 0.1375 \\
2015 & 0.2647 \\
\hline
\end{tabular}

Source: Analysis of secondary data, 2017.

The elasticity of CPO exports (in 2010-2015) is inelastic (Table 3). Changes to CPO prices in Indonesia are not well responded by producers and exporters of CPO by increasing the export volume of CPO to importer countries. This can be explained in various reason, first, In terms of production and availability, this condition can be explained by the time it takes to provide CPO from fresh fruit bunches (FFB) of palm oil to become CPO ready for export.

Second, In terms of marketing, the unfulfilled contracts and ordering of CPO resulted in the absence of new demand for CPO so that exports became impeded. Contractual agreements also result in increased CPO storage costs of domestic export ports, affecting the frequency of CPO shipments and the amount of CPO that can be exported. Indonesia also does not have $\mathrm{CPO}$ shelter in importer country and still sell CPO product of raw form. Development of CPO shelter and down streams CPO products is needed to provide added value to the palm oil industry and accelerate the response to new CPO demand from importer countries. Development of shelter and sale of downstream products will also free Indonesia from CPO export quota in importers country due to the limited $\mathrm{CPO}$ is $\mathrm{CPO}$ in raw form and not CPO derivative products.

Third, In terms of price, the response of IDR exchange rate changes to CPO prices is weak. This can happen because of some things. First, there are barriers exports such as product certification, refusal of Indonesian CPO, and the application of high import duty taxes in importers. Indonesia CPO price should be cheaper because of a devaluation of an exchange rate, but The existence of export barrier makes CPO price Indonesia becomes more expensive and not competitive in the world market. Second, the exchange rate policy is not followed by policies that can mitigate the direct-pass through impact of the exchange rate on inflation. Depreciation of the IDR will result in higher raw material costs. Increased raw material costs will increase CPO production costs. The increase in $\mathrm{CPO}$ production cost makes the exchange rate will not be a stimulus for producers and exporters to increase CPO exports if CPO prices are maintained at the same level. Producers and exporters will respond to increased CPO production costs by increasing CPO selling prices, but an increase in the selling price will reduce CPO demand. The policy to maintain domestic raw material prices is necessary to compensate for the exchange rate depreciation policy in order to keep CPO prices competitive and provide benefits for producers and exporters. Third, there is a lag in the delivery of information, so importers do not realize that there has been a change in prices due to changes in IDR exchange rate policy. Submission of late information makes consumers unaware that CPO prices are cheaper than previous prices after exchange rate depreciation, so consumers do not respond to increasing CPO export demand. Fourth, the price that occurs to the CPO trading process is generally the price of the agreement with the producer and the buyer. The price is fixed and can not be changed because the exchange rate can not respond to CPO prices.

The results that states The elasticity of CPO exports is inelastic in accordance with a research done by Ocran and Biekpe (2008) who found 
that export commodity output was responsive to relative price of food with an elasticity of 0.40 . The elasticity of 0.40 suggests that producers substitute food commodity production for export commodities in the long $\square$ run depending on how favourable food prices are when compared to export prices. The research done by Akinbode (2015) also resulted that export elasticities of gaari and palm oil were inferior food items while others could be classified as normal. The findings of a study about exchange rate volatility and pakistan's exports to major markets done by Alam et al. (2017) concluded the aggregate and bilateral aggregate exports data may weaken the effects of exchange rate volatility to statistically insignificant or less significant, and also that the effect of exchange rate volatility may probably be responsive to the nature of industry producing the exportable goods.

\section{Conclusions}

\subsection{Conclusion}

The major finding of this research is found that the effect of the exchange rate of IDR to U.S. dollar had a weak influence on Indonesian CPO export. This is due to several factors, first from the production side, it takes the time to produce $\mathrm{CPO}$, so increasing the export of CPO also takes time. Second, importers are unaware of price changes due to changes in exchange rate and lag behind decision-making and timing of CPO orders from importer countries. Third, the policy factors, such as the rejection of Indonesian CPO and the imposition of high tax rates. Fourth, CPO producers and exporters are influenced by factors outside the CPO industry such as the development of soybean oil prices and negative issues in the palm industry especially on environmental issues, deforestation, and land fires. The last factor is due to the Indonesian exporters are less creative than Malaysia in marketing CPO products.

Based on ECM analysis, the factors that strongly influenced Indonesian CPO exports were the price of soybean oil and CPO production in the previous month. The factors that have no effect on
Indonesian $\mathrm{CPO}$ export are $\mathrm{CPO}$ prices and $\mathrm{CPO}$ production.

The elasticity analysis results that Indonesia's CPO exports are inelastic. This can be explained in various reason. In term production and availability, its take a time to produce CPO. In term of marketing, the unfulfilled contracts and ordering of $\mathrm{CPO}$ resulted in the absence of new demand for CPO. In term of price, the response of IDR exchange rate changes to CPO prices is weak.

\subsection{Policy Implication}

Some of the things that need to be done to increase Indonesia's CPO exports are: First, there is a need for synergy between government policies that support the downstream of palm oil industry so that CPO exports can be improved and CPO industry can gain added value not only from exporting raw CPO. Second, Indonesian producers and exporters are expected to further improve the quality of $\mathrm{CPO}$ in accordance with standardization of importer countries. This is intended to make the CPO Indonesia more acceptable to the world market and reduce the negative issues of palm oil industry that has grown so far. Third, increased market intelligence for exporters is needed for better distribution of CPO markets. Currently, Indonesian CPO exporters need creativity aimed at increasing Indonesian CPO exports, for example by strengthening bilateral and multilateral trade cooperation, port development and sales of CPO derivative products in importers. Exporters can also divert exports of palm oil products of countries with large prospects of CPO demand such as India, China, Malaysia, Bangladesh, Singapore, Egypt, Pakistan, Brazil, and Kenya. Market expansion of larger areas such as the expansion of regions of Africa, East Asia, and Asia Pacific also needs to be done to gain greater market share.

\section{References}

Abidin, Z. 2008. Analysis of Indonesian Palm Oil Exports. Jurnal Aplikasi Manajemen Vol. 


\section{Jurnal Ekonomi Pembangunan, 18 (2), 2017, 159-174}

06: $139-144$.

Ahmed, S. 2009. Exchange Rate Volatility and International Trade Growth: Evidence from Bangladesh. Munich Personal Repec Archive, 19466.

Akinbode SO. 2015. A linear approximation almost ideal demand system of food among households in South-West Nigeria. International Journal of Social Economics Vol. 42 Issue: 6, pp.530-542[internet]. [cited 2017 Nov 14]. Available from: https://doi. org/10.1108/IJSE-08-2014-0165

Alam S, Ahmed QM, Shahbaz M. 2017. Exchange Rate Volatility and Pakistan's Exports to Major Markets: A Sectoral Analysis. Global Business Review Vol. 18(6) PP. 1-13. [internet]. [cited 2017 Nov 14]. Available from: https://doi.org/10.1177/0972150917713083

Arifin, Sjamsul. 2008. East Asian Economy A Decade After Crisis. Jakarta(ID): PT Elex Computindo.

Baek Jungho. 2007. The J-curve effect and the US-Canada forest products trade. Journal of Forest Economics Vol. 13(4) pp. 245-258[Internet]. [cited 2017 May 14]. Available from: https://doi.org/10.1016/j. jfe.2006.11.001

Chaudhary GM, Hashmi SH, Khan MA. 2016. Exchange rate and foreign trade: A Comparative study of major south Asian and southeast Asian countries. Social and Behavioral Sciences Vol. 230, pp. 85-93.[internet]. [cited 2017 July 7]. Available from: https://doi. org/10.1016/j.sbspro.2016.09.011

Choong Chee Guan, McKay Alison. 2014. Sustainability in the Malaysian palm oil industry. Journal of Cleaner Production 85 pp. 258-264 [Internet]. [cited 2017 Apr 20]. Available from: http://dx.doi.org/10.1016/j. jclepro.2013.12.009

Department of Industry. 2012. Overview of the Palm Oil Industry. Jakarta (ID): Department of Industry of Ministry of Industry of
Indonesia.

[Ditjenbun] Directorate General of Plantation. 2016. Plantation Statistics: Oil Palm. Jakarta (ID): Directorate General of Plantation of Agriculture Ministry of Indonesia.

Efendi, R. and Sawitriyadi. 2009. Determinants of Palm Oil Exports in Indonesia. Jurnal Ekonomi dan Bisnis Vol. 8, No. 3: 247 - 257.

Ervani, E. (2013). Export and Import Performance of Indonesia's Agriculture Sector. JEJAK Journal of Economics and Policy, 6(1). 54-63 doi : 10.15294/jejak.v6i1.3748

[GAPKI] Gabungan Pengusaha Kelapa Sawit Indonesia. 2017. Finding Vegetable Oil Saves Deforestation World. [cited 2017 April 20]. Available from: https://gapki.id/ mencari-minyak-nabati-hemat-deforestasi-dunia.

Hatab AA, Eirik R. 2014. Competitiveness analysis of Egyptian cotton exports with special focus on the Chinese market. China Agricultural Economic Review. Vol. 6 Iss 2 pp. 248 - 263 [Internet]. [cited 2017 feb 15]. Available from: http//dx.doi.org/10.1108/ CAER-02-2013-0026

Khalighi L, Fadaei MS. 2017. A study on the effects of exchange rate and foreign policies on Iranians dates export. Journal of the Saudi Society of Agricultural Sciences vol. 16 pp. 112-118 [internet]. [cited 2017 July 7] available from : http://dx.doi.org/10.1016/j. jssas.2015.03.005

Kumar, Dilip. 2014. Correlations, Return and Volatility Spillovers in Indian Exchange Rates. Global Business Review Vol. 15(1) PP. 77-91[internet]. [cited 2017 Nov 14]. Available from: https://doi. org/10.1177/0972150913515577

Lee, Chun-Chang. 2013. Interaction between House Prices, stock Prices and Monetary Policy-Using Recursive VAR [internet]. [cited 2017 feb 14]. Available from: http:// dx.doi.org/10.4236/ajibm.2013.38074. 


\section{Jurnal Ekonomi Pembangunan, 18 (2), 2017, 159-174}

Maryatmo R. 2010. The influence of short-term and long-term changes in interest rates and IDR exchange rate against stock prices: Empirical studies in Indonesia (2000:1-2010:4). JEJAK Journal of Economics and Policy 3 (1):1-11 doi : 10.15294/ jejakv3i1.4660

Mukherjee Ishani, Sovacool Benjamin K. 2014. Palm oil - based biofuels and sustainability in southeast Asia : A review of Indonesia, Malaysia, and Thailand. Renewable and Sustainable Energy Reviews $37 \mathrm{pp}$. 1-12 [Internet]. [cited 2017 feb 14]. Available from: http://www.sciencedirect.com/ science/journal/13640321 doi: 10.1016/j. rser.2014.05.001.

Nanang DM. 2010. Analysis of export demand for Ghana's timber products: A multivariate co-integration approach. Journal of Forest Economics Vol. 16 (1), 47-61. [Internet]. [cited 2017 May 14]. Available from : https://doi.org/10.1016/j.jfe.2009.06.001

Ocran MK, Biekpe N. 2008. Agricultural commodity supply response in Ghana. Journal of Economic Studies, Vol. 35 Issue: 3 pp. 224-235 [internet]. [cited 2017 Nov 14]. Available from: https://doi. org/10.1108/01443580810887788

Oosterveer, Peter. 2015. Promoting sustainable palm oil : viewed from a global network and flows perspective. Jurnal of Cleaner Production 107 page 146-153 [Internet]. [cited 2017 feb 14]. Available from: http://www. sciencedirect.com/science/journal/09596526 doi: 10.1016/j.jclepro.2014.01.019

Peñarandaa RM, Gasparatosb A, Strombergc P, Suwad A, Pandyaswargoe AH, Oliveira JAP. 2015. Sustainable production and consumption of palm oil in Indonesia: What can stakeholder perceptions offer to the debate?. Sustainable Production And Consumption 4 pp. 16 - 35 [Internet]. [cited 2017 feb 15]. Available from: http://www. sciencedirect.com/locate/spc doi: 10.1016/j. spc.2015.10.002.

Rosita Ratih, Haryadi, Amril. 2014. Export Determinant of Indonesian CPO. Jurnal Perspektif Pembiayaan dan Pembangunan Daerah Vol. 1 No. 4: 183-190.

Salvatore, Dominick. 2009. Microeconnomics 5th Edition. London (UK): Oxford University Press.

Seyoum, Belay. 2009. Export-Import Theory, Practices, and Procedures Second Edition. New York (US): Routledge

Sonaglio CM, Campos AC, Braga MJ.2016. Effects of interest and exchange rate policies on Brazilian exports. EconomiA Vol.17 (1) pp. 77-95 [internet]. [cited 2017 July 7]. Available from: https://doi.org/10.1016/j. econ.2016.01.02

Subiyakto, H., \& Algifari, A. (2016). Cointegration and Causality Test Among Export, Import, and Foreign Exchange. JEJAK: Jurnal Ekonomi Dan Kebijakan, 9(1),82-96. doi: 10.15294/jejak.v9i1.7188

Sulistyanto, I. S dan R. Akyuwen. 2011. Factors Affecting the performance of Indonesia's Crude Palm Oil Export. IPEDR vol.4 IACSIT Press. Singapore (SG): International Conference on Economics and Finance Research.

Sumantyo R dan Anggraeni D. 2016. The Effect of BI Rate's Decrease Toward The Market Reaction in Indonesia Stock Exchange (IDX). [cited 2017 may 23]. Available from: http:// journals.ums.ac.id/index.php/JEP/article/ view/2747 doi: 10.23917/jep.v17i2.2747

Syaukat, Y. 2010. Creating Economic Competitiveness and Environment of Indonesian Palm Oil Industry. Agrimedia 15 (1) Juni 2010: 16 - 19 .

[USDA] United States Department of Agriculture. 2017. Oil Seeds: World Market and Trade. Washington (US): Foreign Agricultural Service United States Department of 


\section{Jurnal Ekonomi Pembangunan, 18 (2), 2017, 159-174}

\section{Agriculture}

Wibowo, Larasati Sukmadewi. 2015. Factor Influencing Crude Palm Oil (CPO) Biodiesel Supply in Indonesia Using Error Correction Model (ECM). Business and Economic Research 5.1 (2015): 133-144.

Widyastutik dan Asiqin AZ. 2011. Competitiveness analysis and factors affecting Indonesia's cpo exports to china, malaysia and singapore in the asean-china free trade agreement. Jurnal management \& agribisnis Vol. 8 N0.2. Available From: http:// dx.doi.org/10.17358/jma.8.2.65-73

Zhang Han, Zhao Q, Kuuluvainen J, Wang C, Li S. 2015. Determinants of China's lumber import: A bounds test for cointegration with monthly data. Journal of Forest Economics Vol. 21 (4), pp. 269-282[Internet]. [cited 2017 May 14]. Available from : https://doi. org/10.1016/j.jfe.2015.10.002 
Jurnal Ekonomi Pembangunan, 18 (2), 2017, 159-174

\section{Appendix}

The classical assumption test was performed to provide assurance that the regression equation obtained has precision in estimation, unbiased and consistent (Best Linear Unbiased Estimator ). Good model testing to conform to classical assumptions was done by multicollinearity test, autocorrelation test, and heteroskedasticity test. Table 1 shows the classical assumption test that has been done in this research, it wass concluded that the classical assumption of the regression model has been fulfilled so that the regression equation obtained was not biased either in estimator or in error.

Table 1. Classic Assumption Test Regression Model

\begin{tabular}{|c|c|c|}
\hline $\begin{array}{c}\text { Classic assumption } \\
\text { test }\end{array}$ & Methods & Information \\
\hline Normality & Jarque-Bera & $\begin{array}{l}\text { Based on secondary data analysis, Jarque-Bera value of } 2.38 \\
\text { with probability value }(0,30) \text { is greater than a }(5 \%) \text {, it means } \\
\text { that distribution data is normally distributed. }\end{array}$ \\
\hline Multicolinearity & $\begin{array}{l}\text { Correlation coef- } \\
\text { ficient }\end{array}$ & $\begin{array}{l}\text { The value of correlation coefficient between each independent } \\
\text { variable is in the range } 0.22-0.67 \text { and below } 0.85 \text {, so it can be } \\
\text { concluded that not found multicollinearity in the model }\end{array}$ \\
\hline Autocorrelation & $L M$ test & $\begin{array}{l}\text { Obtain * R-squared value of } 2.40 \text { with probability Chi-square } \\
\text { of } 0.29 \text { greater than a } 0.05(5 \%) \text {, then concluded in the equation } \\
\text { model there is no autocorrelation. }\end{array}$ \\
\hline Heteroscedasticity & White Test & $\begin{array}{l}\text { Obtain value of squared residuals }\left(\mathrm{ui}^{2}\right) \text { with chi-squared prob- } \\
\text { ability of } 0.49 \text { is greater than a } 0.05(5 \%) \text {, it is concluded that } \\
\text { the model is free from heteroskesdaticity }\end{array}$ \\
\hline
\end{tabular}

Source: Analysis of secondary data, 2017. 